\title{
Transitivity Analysis of American President Donald Trump's Inaugural Address
}

\author{
Zhu Yujie, Li Fengjie \\ Foreign Languages Department, School of Humanities, Tianjin University of Finance and Economics, Tianjin, China
}

Email address:

yyfx0901@163.com (Li Fengjie)

\section{To cite this article:}

Zhu Yujie, Li Fengjie. Transitivity Analysis of American President Donald Trump's Inaugural Address. International Journal of Literature and Arts. Vol. 6, No. 2, 2018, pp. 28-34. doi: 10.11648/j.ijla.20180602.11

Received: April 13, 2018; Accepted: May 8, 2018; Published: May 31, 2018

\begin{abstract}
Political public speeches cause a large amount of attention, due to their political, economic and cultural influence. This thesis adopts Systemic-Functional Grammar as its theoretical framework to conduct a transitivity analysis in American President Donald Trump's Inaugural Address. The aim of this thesis is to find the political motivation hidden by the form of language. At the same time, this thesis tries to explore the deep social significance via transitivity analysis of the ideational function. In Donald Trump's Inaugural Address, the material process is the most frequently used process. The relational process and the mental process take the second and the third respectively. In transferring power to the people, material process is strongly involved. In advocating for U.S. interests in international contacts -- America first, relational process top the list of all the six processes. In recovering the audience's confidence and looking forward to a better future, American President Donald Trump applied different mental processes. On the basis of the study, the researchers can better understand the thinking manner and cultural features of Westerners. Besides, it is a worthy study to uncover more differences of language expression between the East and the West.
\end{abstract}

Keywords: Process, Transitivity, Functional Linguistics, Trump's Inaugural Address

\section{Introduction}

\subsection{Research Background}

Halliday [4] has researched the Inheritors written by William Golding from the perspective of transitivity, which becomes the first application of Systematic Functional Grammar to analyze literary works. Huang Guowen [15] studies six English versions of the Chinese poem "Qingming" by using Interpersonal Function theory. He mainly focuses on the characters in the poem. And Zhu Yongsheng [8] studies thematic progression patterns and discourse analysis. When it comes to using Systematic Function Grammar to analyze political speeches, many scholars have studied them. Such scholars as Wang Fang [13], Kong Jing [11], Liu Ming [12] and so on. The common characteristics of their thesis lie in that they only can concentrate on one aspect of their meta-functions and they hardly have any theoretical innovations. Few scholars have studied a piece of political speech from ideational function.

The present thesis applied transitivity analysis in Halliday's systemic functional grammar approach to the study of American President Donald Trump's Inaugural Address to work out the transitivity distribution of six transitivity processes in this speech and pragmatic functions of each transitivity type. The interrelated research questions are as follows:

What are the distributions of transitivity processes in American President Donald Trump's Inaugural Address?

What are the functions of each transitivity process type in American President Donald Trump's Inaugural Address?

\subsection{Research Design}

On the basis of Halliday's systematic functional grammar, the present study is designed to analyze the linguistic features of the American newly-elected President Donald Trump's Inaugural Address by the method of transitivity analysis. In this study, an investigation is conducted on the process types in this speech and the results were analyzed quantitatively by using descriptive statistics.

In order to get the reliable research results, the speech was downloaded from the official website of American 
government www.whitehouse.gov/. (see appendix).

To conduct transitivity analysis of American President Donald Trump's Inaugural Address, we first identify all the ranking clauses, the basis of the process types, in this speech, which is followed by the identification of the process types defined by Halliday [4].

\subsection{Significance}

In the inaugural speech which is usually delivered to the people both at home and abroad, the speaker is expected to show his political stand and view, make his government policy known to the public to accept and support his policy. The inaugural is significant because it reflects the fundamental political values. The inaugural address usually plays an important role in teaching and encouraging the citizens. So the new president impresses the public through carefully weighing his words and polishing his address.

Based on Halliday's Systematic Functional Grammar, this thesis, by analyzing American President Donald Trump's Inaugural Address, attempts to find the political motivation hidden by the form of language. At the same time, it tries to explore the deep social significance via transitivity analysis of the ideational function.

\section{Theoretical Framework}

\subsection{Three Metafunctions}

The term metafunction originates in systemic functional linguistics and is considered to be a property of all languages. According to Halliday, though languages vary in how and what they do, and what humans do with them in the contexts of human cultural practice, all languages are considered to be shaped and organized in relation to three functions, or metafunctions. Halliday's functional grammar contains three metafunctions as follows: (a) Language is used to convey the new information, to communicate the content that is unknown to the hearer. This function is known as the ideational function. (b) the interpersonal function embodies all uses of language to express social and personal relations. This includes the various ways the speakers enter a speech situation and perform a speech act. (c) the textual function refers to the fact that language has mechanism to make any stretch of spoken or written discourse into a coherent and unified text and make a living passage different from a random list of sentences. According to Halliday, a clause is the simultaneous realization of ideational, interpersonal and textual meanings.

\subsection{Ideational Function}

Language is used to organize, understand and express people's perceptions of the world and of their own consciousness. This function is known as the ideational function. The ideational function can be classified into two sub-functions: the experiential and the logical. The experiential function is largely concerned with content or ideas. The logical function is concerned with the relationship between ideas. On the one hand, ideational function represents their direct experience; therefore, the function is experiential. On the other hand, it also represents the abstract logical relations people perceive and drive from their experience; therefore, the function is also logical.

\subsection{Transitivity}

The English clause has transitivity, that is, it matches our experience of a real life event. The term transitivity used in Systemic Functional Grammar is a semantic category, which is a reflection of human being's recognition at the lexicogrammar level both in written and spoken form with the choice of process types and participant and circumstantial element.

The transitivity system construes the world of experience into a manageable set of process types. A process is composed of three semantic categories: the processes, the participants involved and the circumstances as mentioned above.

There are six types of processes in the transitivity system: they can be sub-classified into three major ones: material, mental and relational and three minor ones: verbal, behavioral and existential.

The material process (MA) can be said to involve "doing" words. It expresses the notion that some entity "do" something to some other entity. The "doer" of this type of action is called Actor. Any material process has an Actor, even though the Actor may not be mentioned in the clause. In many clauses, the action may be represented as "affecting" or "being done to" a second participant, which is called Goal. However, material processes are not necessarily concrete, physical event. They may be abstract doing and happening. The Actor may also be an inanimate or abstract entity, and the goal may be human or non-human as the table below shows.

Table 1. Material process.

\begin{tabular}{lll}
\hline We & will seek & friendship \\
A new vision & will govern & our land \\
We & defend & other nation's borders \\
Actor & Process: material & Goal \\
\hline
\end{tabular}

A mental process (ME) accounts for the process of sensing. There are clear differences between something that goes on in the external world and something that goes on in the internal world of the mind. There are many verbs which refer to these mental processes, of thinking, imaging, liking, wanting, seeing, etc. Halliday further offered three subcategories of the mental process: Perception (hearing), Affection (liking, hating) and Cognition (thinking, understanding). Tompson [3] also gave four criteria for distinguishing between material and mental processes. This first is that mental processes always involve at least one human participant. Second, criterion is that the kind of entity which can fill the role of the other participant in a mental process is less restricted than the entities which can act as participants in a material process. The third reason for differentiating between material and mental process is tense. The fourth is that mental processes are reversible. 
Table 2. Mental process.

\begin{tabular}{lll}
\hline We & will no longer accept & politicians \\
We all & enjoyed & the same glorious freedom \\
American & want & great school for their children \\
Senser & Process: mental & Phenomenon \\
\hline
\end{tabular}

The verbal process (VE) is the process of "saying". "Saying" covers any kind of symbolic exchange of meaning. This process is intermediate between mental and material processes. The central verbal process, nevertheless, is easily recognized in that it is related to the transfer of message through language. One participant in any verbal process is Sayer -- the person who speaks though sometimes need not be explicitly mentioned in the clause.

Table 3. Verbal process.

\begin{tabular}{lll}
\hline The Bible & tells & us how good it is \\
We & must speak & our minds openly \\
She & told & one interviewer \\
Sayer & Process: verbal & Receiver \\
\hline
\end{tabular}

Relational processes (RE) are processes of "being". Examples are She is our monitor, John is stupid. As the term relational suggests, this is not being in the sense of existing. There is a related category of existential clauses. In relational clause, there are two parts to the being, something is being said to be something else. In other words, a relationship is being set up between two separate entities.

Every language accommodates, in its grammar, some systematic construction of relational processes. The English system operates with three main types:

(a) Intensive: $x$ is a

(b) Circumstantial: $x$ is at a

(c) Possessive: $x$ has a

There are two modes of relational processes:

(1) attributive: $a$ is an attribute of $x$

(2) identifying: $a$ is the identity of $x$

Table 4. Relational process.

\begin{tabular}{lll}
\hline This moment & is & your moment \\
Whether we & are & black or brown or white \\
Today's ceremony & has & very special meaning \\
Carrier/Identified & Process: relational & Attribute/Identifier \\
\hline
\end{tabular}

The existential process (EX) represents that something happens or exists. It expresses the only existence of any entity without predicating anything else of it. It is easily recognizable because of the empty subject there and copulative verb be. Of course there are some other verbs indicating this process for example arise. Only one participant is Existent.

Table 5. Existential process.

\begin{tabular}{lll}
\hline There & should be & no fear \\
A nation & exist & to serve its citizen \\
There & was & little to celebrate \\
& Process: existential & Existent \\
\hline
\end{tabular}

Behavioral processes (BE) are processes of (typically human) physiological and psychological behavior, like breathing, coughing, smiling, dreaming and starting. They are intermediate between mental and material process. It also has only one participant-- Behaver, the person who is behaving. In some clauses, there may be another apparent participant, typically functioning as complement, the Range, which is not a real participant but merely adds specification to the process.

Table 6. Behavioral process.

\begin{tabular}{lll}
\hline We all & bleed & the same red blood of patriots \\
All Americans & hear & these words \\
We all & salute & the same great American flag \\
Behaver & Process: behavioral & Range \\
\hline
\end{tabular}

We have now completed this survey of process types in English and the participant roles associated with each. A figure summarizes the categories that have been set up.

Table 7. Six processes.

\begin{tabular}{lll}
\hline Process type & Core meaning & Participants \\
\hline Material & Doing, happening & Actor, goal \\
Mental & Sensing & Senser, phenomenon \\
Perception & Perceiving & \\
Cognition & Thinking & \\
Affection & Feeling & \\
Relational & Being & \\
Attributive & Attributing & Carrier, attribute \\
Identifying & Identifying & Identified, identifier \\
Verbal & Saying & Sayer, receiver \\
Behavioral & Behaving & Behaver \\
Existential & Existing & Existent \\
\hline
\end{tabular}

\section{Transitivity Analysis of American President Donald Trump's Inaugural Address}

\subsection{Distribution of Six Processes in American President Donald Trump's Inaugural Address}

Table 8 shows the total number of the different processes in clauses of this political speech (see appendix).

Table 8. Distribution of six processes.

\begin{tabular}{lll}
\hline Name of processes & $\begin{array}{l}\text { Number of this } \\
\text { process }\end{array}$ & $\begin{array}{l}\text { Percentage of this } \\
\text { process }\end{array}$ \\
\hline Material & 130 & $64.67 \%$ \\
Relational & 30 & $14.92 \%$ \\
Mental & 24 & $11.94 \%$ \\
Verbal & 5 & $2.48 \%$ \\
Existential & 5 & $2.48 \%$ \\
Behavioral & 7 & $3.48 \%$ \\
Total & 201 & $100 \%$ \\
\hline
\end{tabular}

A total of 201 clauses are found in this president's inaugural address and all the six process types are found to have occurred in the address. As shown in Table8, the material process is the most frequently used process type with a total 
occurrence of $(64.67 \%)$, followed by the relational process $(14.92 \%)$, the mental process $(11.94 \%)$, the verbal process $(2.48 \%)$, the existential process $(2.48 \%)$, and the behavioral process $(3.48 \%)$. Significant differences are found in the frequencies of the six process types in this speech, which will be further discussed in the following sections.

\subsection{Distribution and Functions of Transitivity Processes in President Donald Trump's Inaugural Address}

American newly-selected president Donald Trump's inaugural address is generally divided into two parts, that is, advocating for U.S. interests in international contacts -America first, transferring power to the people and recovering the audience's confidence and looking forward to a better future. The three parts will be taken a whole respectively to conduct an analysis of transitivity process.

Material process can actually be said to involve "doing". The application of this type of process indicates that the writer/speaker is intentionally hoping the reader/listener to react. The table 8 has shown that material processes appear most frequently in President Donald Trump's Inaugural Address and percentage of material process is the highest of all the process types. It shows that the percentage of material process is as high as $64.67 \%$, which indicates that material process accounts for half of the top process. Material processes are processes of doing. They express the notion that some "entity" does something which may be done to "some other entity".

In tracing back to transferring power to the people, material processes are strongly involved in. Material processes from transferring power to the people are as follows:

(1) Because today, we are not merely transferring power from one administration to another or from one party to another.

(2) But we are transferring power from Washington D.C. and giving it back to you, the people.

Relational process in President Donald Trump's Inaugural Address holds $14.92 \%$ of all the processes. Although being less than that of material process the percentage is far higher than those of other processes. Among the 30 relational processes, there are 17 attributive processes taking a much larger part of $58 \%$, in contrast to identifying processes which take up only $42 \%$ in all of the relational processes in this speech.

(1) ... it's to be only America first -- America first.

(2) ... it is the right of all nations to put their own interests first.

(3) When America is united, America is totally unstoppable.

All these relational processes show that America is truly in a serious all-around level. Early in his inaugural address, he made it crystal clear that they are indeed burdens: These are just and reasonable demands of.... this movement is a crucial conviction.... At the bedrock of our politics will be a total allegiance to....

The third frequently used type of process is mental process. Mental process is "a process of sensing". It involves phenomena described as state of mind our psychological events. It expresses affection, cognition and perception in President Donald Trump's Inaugural Address, mental processes largely distributes in the recovering the audience's confidence and looking forward to a better future. Mental processes from the recovering the audience's confidence and looking forward to a better future are as follows:

(1) January 20th, 2017 will be remembered as the day the people became the rulers of this nation again.

(2) A new national pride will stir ourselves, lift our sights and heal our divisions.

(3) We all enjoyed the same glorious freedoms, and we all salute the same great American flag.

(4) Finally, we must think big and dream even bigger.

To encourage the people, Donald Trump used many mental processes to fulfill different effects. He applied different mental process verbs to different sensors, which shows his different attitudes and subjective emotion.

The remaining three types accounts for a small proportion. Existential processes are used to show realistic society of the United States. The reality is totally different from people's expectations.... there was little to celebrate for struggling families all across our land....that a nation exist to serve its citizens. Donald Trump making use of verbal process and behavioral process appeals to people to maintain and exercise the right. We must speak our minds openly, debate our disagreement.... We stand at the birth of a new millennium...

\section{Conclusion}

The study in the thesis has applied the transitivity system in analyzing American President Donald Trump's Inaugural Address. The quantitative analysis has proved the transitivity system in SFG an effective method in encoding and decoding this political public speech. Some major findings of the study are summarized as follows.

(a) All the six processes types were found to have occurred in the address. The material process was the most frequently used process. The relational process and the mental process take the second and the third respectively. The last three processes are verbal process, existential process and behavioral process in a descending order of the occurrence frequencies. In different parts of Donald Trump's Inaugural Address, different processes are prominent.

(b) President's Inaugural Address is one of the typical political speeches with specific political aims. The speaker can convey his idea only through his speech. So the politicians usually choose more objective and more persuasive processes to reach their goals. Both material and relational processes are the best options for their political aims, because material and relational processes presented as the statement of reality from the perspective of onlookers. They seem to be more objective than other processes.

(c) In transferring power to the people and the power belonging to the people, material processes are strongly involved. In the President Donald Trump's Inaugural Address material processes are used to emphasize the fact that the 
people became the rulers of nation and what truly matters is not which party controls the government but whether the government is controlled by the people.

(d) In advocating for U.S. interests in international contacts -- America first, relational processes top the list of all the six processes. All these relational processes show that it is the right of all nations to put their own interests first. Relational process is a method with objective evaluation and judgment, so the audience will be more ready to receive the idea conveyed from the speaker.

(e) In recovering the audience's confidence and looking forward to a better future, American president Donald Trump applied different mental process verbs to express different emotions, which shows his different attitudes and subjective emotions. To the people of nations, Donald Trump apply mental process to encourage them. A new national pride will stir themselves, lift their sights and heal their divisions.

Transitivity system is a key perspective of text teaching. This can be taken as a vivid example on applications of transitivity analysis in the thesis. Through examining main processes of a text, a listener can better grasp the ideational function of the text and choices of words. Meanwhile, teachers also can enhance listeners' functional awareness and appreciative ability.

English Foreign Language teachers need to guide readers to effective reading. In the course of teaching, teachers could have students focus on prominent transitivity features regarding processes. For example, teachers could start by asking questions like "do you realize in this article, what kind of processes does the author choose to express the event ?" A useful follow-up step would be to ask, "what is the function of these process choice?" At the same time, teachers could choose several texts for the students to read comparatively.

By introducing transitivity analysis in English language teaching, we not only help the listeners advance their reading comprehension, and their competence to understand the world, but help them probe into the essence of utterances.

On completing the thesis, there are also some limitations in the study. Firstly, the number of the samples should be more adequate if aiming at arriving at a more complete and convincing conclusion. Also, while much attention of the study has been paid to revealing the transitivity features of Inaugural Address, insufficient research has been conducted into the explorations of pragmatic functions of transitivity types. Lastly, the study of the participants and circumstantial elements may add more enlightenment in transitivity analysis.

In light of the outcome of the study, researchers perceive several areas deserving further research. Besides further improvements mentioned above, many political conceptual metaphors have occurred in American President Donald Trump's Inaugural Address. They are worthy to be studied to uncover more hidden public speech skills and political opinions.

\section{Appendix}

Inaugural Address By President Donald Trump
Chief Justice Roberts, President Carter, President Clinton, President Bush, President Obama, fellow Americans and people of the world, thank you.(ME)

We, the citizens of America, are now joined (MA) in a great national effort to rebuild (MA) our country and restore (MA) its promise for all of our people. Together we will determine (MA) the course of America and the world for many, many years to come (MA).

We will face (MA) challenges. We will confront (MA) hardships. But we will get (MA) the job done(MA). Every four years, we gather(MA) on these steps to carry out (MA) the orderly and peaceful transfer of power.

And we are (RE) grateful to President Obama and First Lady Michelle Obama for their gracious aid throughout this transition. They have been (RE) magnificent. Thank you.(ME)

Today's ceremony, however, has (RE) very special meaning. Because today, we are not merely transferring (MA) power from one administration to another or from one party to another.

But we are transferring (MA) power from Washington D.C. and giving (MA) it back to you, the people.

For too long, a small group in our nation's capital has reaped (MA) the rewards of government while the people have borne (MA) the cost. Washington flourished (MA), but the people did not share (MA) in its wealth. Politicians prospered (MA), but the jobs left (MA). And the factories closed (MA).

The establishment protected (MA) itself but not the citizens of our country. Their victories have not been (RE) your victories. Their triumphs have not been (RE) your triumphs. And while they celebrated (MA) in our nation's capital, there was (EX) little to celebrate (MA) for struggling families all across our land. That all changes starting (MA) right here and right now. Because this moment is(RE)your moment. It belongs to (RE) you.

It belongs to (RE) everyone gathered (MA) here today and everyone watching (BE) all across America. This is (RE) your day. This is (RE) your celebration. And this, the United States of America, is (RE) your country.

What truly matters (MA) is (RE) not which party controls (MA) our government but whether our government is controlled (MA) by the people. January 20th, 2017 will be remembered $(\mathrm{ME})$ as the day the people became $(\mathrm{RE})$ the rulers of this nation again.

The forgotten men and women of our country will be forgotten (ME) no longer.

Everyone is listening (BE) to you now. You came (MA) by the tens of millions to become (RE) part of a historic movement, the likes of which the world has never seen (ME)before.

At the center of this movement is (RE) a crucial conviction -- that a nation exist (EX) to serve (MA) its citizens. Americans want (ME) great schools for their children, safe neighborhoods for their families and good jobs for themselves.

These are (RE) just and reasonable demands of righteous people and a righteous public. But for too many of our citizens, a different reality exist (EX). Mothers and children trapped 
(MA) in poverty in our inner cities, rusted (MA) out factories scattered (MA) like tombstones across the landscape of our nation, an education system flushed (MA) with cash but which leaves (MA) our young and beautiful students deprived (MA) of all knowledge. And the crime, and the gangs, and the drugs that have stolen (MA) too many lives and robbed (MA) our country of so much unrealized potential. This American carnage stops (MA) right here and stops (MA) right now.

We are (RE) one nation, and their pain is (RE) our pain. Their dreams are (RE) our dreams, and their success will be (RE) our success. We share (RE) one heart, one home and one glorious destiny.

The oath of office I take (MA) today is (RE) an oath of allegiance to all Americans. For many decades, we've enriched (MA) foreign industry at the expense of American industry, subsidized (MA) the armies of other countries while allowing (MA) for the very sad depletion of our military.

We defend (MA) other nation's borders while refusing (MA) to defend (MA) our own and spent (MA) trillions and trillions of dollars overseas while America's infrastructure has fallen (MA) into disrepair and decay.

We've made (MA) other countries rich while the wealth, strength, and confidence of our country has dissipated (MA) over the horizon. One by one, the factories shuttered (MA) and left (MA) our shores with not even a thought about the millions and millions of American workers that were left (MA) behind.

The wealth of our middle class has been ripped (MA) from their homes and then redistributed (MA) all across the world.

But that is (RE) the past and now we are looking (BE) only to the future.

We assembled (MA) here today are issuing (MA) a new decree to be heard (ME) in every city, in every foreign capital and in every hall of power. From this day forward, a new vision will govern (MA) our land. From this day forward, it's going to be (RE) only America first -- America first.

Every decision on trade, on taxes, on immigration, on foreign affairs will be made (MA) to benefit (MA) American workers and American families. We must protect (MA) our borders from the ravages of other countries making (MA) our products, stealing (MA) our companies and destroying (MA) our jobs.

Protection will lead (MA) to great prosperity and strength. I will fight (MA) for you with every breath in my body. And I will never, ever let (MA) you down.

America will start winning (MA) again, winning (MA) like never before.

We will bring (MA) back our jobs. We will bring (MA) back our borders. We will bring (MA) back our wealth, and we will bring (MA) back our dreams. We will build (MA) new roads and highways and bridges and airports and tunnels and railways all across our wonderful nation. We will get (MA) our people off of welfare and back to work (MA) rebuilding (MA) our country with American hands and American labor. We will follow (MA) two simple rules -- buy (MA) American and hire (MA) American.

We will seek (MA) friendship and goodwill with the nations of the world.

But we do (MA) so with the understanding that it is (RE) the right of all nations to put (MA) their own interests first. We do not seek (MA) to impose (MA) our way of life on anyone but rather to let (MA) it shine (MA) as an example. We will shine (MA) for everyone to follow (MA).

We will reinforce (MA) old alliances and form (MA) new ones, and unite (MA) the civilized world against radical Islamic terrorism, which we will eradicate (MA) completely from the face of the earth.

At the bedrock of our politics will be (RE) a total allegiance to the United States of America and through our loyalty to our country, we will rediscove (MA) our loyalty to each other. When you open (MA) your heart to patriotism, there is (EX) no room for prejudice.

The Bible tells (VE) us how good and pleasant it is (RE) when God's people live (MA) together in unity. We must speak (VE) our minds openly, debate (VE) our disagreement honestly but always pursue (MA) solidarity. When America is united (MA), America is (RE) totally unstoppable.

There should be (EX) no fear. We are protected (MA), and we will always be protected (MA). And most importantly, we will be protected (MA) by the great men and women of our military and law enforcement. We will be protected (MA) by God.

Finally, we must think (ME) big and dream (ME) even bigger. In America, we understand (ME) that a nation is only living (MA) as long as it is striving (MA). We will no longer accept (ME) politicians who are (RE) all talk and no action, constantly complaining (VE) but never doing (MA) anything about it.

The time for empty talk is (RE) over. Now arrives (MA) the hour of action.

Do not allow (MA) anyone to tell (VE) you that it cannot be done (MA). No challenge can match (MA) the heart and fight (MA) the spirit of America. We will not fail (MA). Our country will thrive (MA) and prosper (MA) again. We stand (BE) at the birth of a new millennium, ready to unlock (MA) the mysteries of space, to free (MA) the earth from the miseries of disease and to harness (MA) the energies, industries and technologies of tomorrow. A new national pride will stir (ME) ourselves, lift (ME) our sights and heal (ME) our divisions. It's (MA) time to remember (ME) that old wisdom our soldiers will never forget (ME) -- that whether we are $(\mathrm{RE})$ black or brown or white, we all bleed (BE) the same red blood of patriots.

We all enjoyed (ME) the same glorious freedoms, and we all salute (BE) the same great American flag.

And whether a child is born (MA) in the urban sprawl of Detroit or the windswept plains of Nebraska, They look (BE) up at the same night sky, they build (MA) a heart with the same dreams and they are infused (MA) with the breath of life by the same Almighty Creator.

So to all Americans in every city near and far, small and large, from mountain to mountain, from ocean to ocean, hear (ME) these words -- you will never be ignored (ME) again.

Your voice, your hopes and your dreams will define (ME) 
our American destiny. Together, And your courage and goodness and love will forever guide (MA) us along the way. We will make (MA) America strong again. We will make (MA) America wealthy again. We will make (MA) America proud again. We will make (MA) America safe again. And yes, together, thank you.(ME) we will make (MA) America great again. God bless (ME) you. And God bless (ME) America. Thank You.(ME)

\section{References}

[1] Abne M. Eisenberg \& Teri Kwal Gamble. Painless Public Speaking. Lanham Md.: University Press of America, 1991.

[2] Bloor, T. and M. Bloor. The Functional Analysis of English: A Hallidayan Approach [M]. Beijing: Foreign Language Teaching and Research Press, 2000.

[3] Brown, G, Yule, G Discourse Analysis [M] Beijing: Foreign Language Teaching and Research Press, 2000.

[4] Halliday, M. A. k. An Introduction to Functional Gramma $r$ (second edition.) [M] Beijing: Foreign Language Teaching and Research Press, 2000.

[5] Lucas, S. E. The Art of Public Speaking (eighth edition.) [M] Beijing: Foreign Language Teaching and Research Press, 2000.

[6] Thompson, G. Introducing Functional Grammar [M] Beijing: Foreign Language Teaching and Research Press, 2000.

[7] Hu Zhuanglin. The System and function of Language [M] Beijing: Peking University Press, 1990.
[8] Xin Bin. A Critical Analysis of English Discourse [J]. Sichuan Journal of Foreign Language, 1997, 4.

[9] Xiong Li. The Stylistic Style of Kennedy's Speech from the Inaugural Speech [J] Journal of Southwest University for Nationalities, 2004, 12.

[10] Zhang Huisong. The Exploration of the Transitivity System in English [J]. Journal of Hunan Normal College, 1996, 2.

[11] Hu Zhiying. Analysis of Obama's Victory Speech in 2012 from Halliday's Three Meta-function. Master Thesis. Human: Hunan Agriculture University, 2014, 6.

[12] Zhang Mingming. Transitivity Analysis of Hillary Clinton's Speech [J]. Literature of Times 23(2), 20-24, 2013.

[13] Zhangping, Halliday's Transitivity and Translation. Master Thesis. Changsha: Hunan Normal University, 2013.

[14] Laya, H. D. Persuasive Style and its Realization Through Transitivity Analysis: A SFL Perspective [J]. Procedia-Social and Behavioral Science (118):172-175, 2014.

[15] Huang Guowen. Text Analysis Summary [M]. Changsha: Hunan Education Press, 2003.

[16] Zhangting. Ideational Function Analysis of the English translation of the Songs of Chu. Journal of Hubei University For Nationalities. 2016, 34.

[17] Wu Jianguo, Chen Congying. Review of Critical Discourse Research 2015 [J]. Guangzhou: Journal of Tianjin Foreign Studies University. 2016, 3. 